\title{
ELIE MERLAT ON DISCERNMENT OF FALSE INSPIRATION
}

The problem of discerning true from false prophecy arises in the Old and New Testaments, for example in the warning of Moses (Deut. 18, 2122) and Jeremiah and in the admonition to « test the spirits, to see if they come from God " in the first letter of John (1 John 4, 1). The perennial problem for those in the Judeo-Christian tradition claiming divine inspiration as their source for prophecy was to prove that they were not victims of self-deceit or an evil power.

A new challenge to the discernment of true from false inspiration arose with the outpouring of prophetic messages by lay persons in the Dauphine and Languedoc in 1688. In October 1685 the Revocation of guarantees extended by the Edict of Nantes to members of the Reformed Church in France put its formal seal on a process of deterioration of these rights. The most devastating blow intended by the Edict of Revocation was the expulsion of all Protestant ministers from France. It was assumed that the faithful, deprived of their pastoral care and spiritual support, would succumb to conversion, a road thousands under exasperating pressure had previously chosen. The expectations of the Crown, however, were disappointed and instead of mass conversion a mass exodus of over 200000 Huguenots occurred, despite the decree of 1699 that forbade Protestants to leave the country. Among those, approximately 150000 , who chose to remain and defy Catholicization, a willingness was nurtured to suffer and bear martyrdom for their cause ${ }^{1}$. Accustomed to worship in their homes, they continued in secret the familiar forms of service. In Languedoc and Dauphine lay preachers, the Prédicants, arose to meet the pastoral needs of the Huguenots. They assembled in remote and wild

1. Elisabeth LABrousse, “Calvinism in France 1598-1685 ", in International Calvinism, ed. by Menna Prestwich, Oxford, Clarendon Press, 1985, p. 310, and Charles Bost, Les Prédicants Protestants des Cévennes et du Bas-Languedoc 1684-1700, Paris, Honoré Champion, 1912, vol. I, p. 36.

Revue de synthèse : IV S. N 4, oct.-déc. 1990. 
places, soon designated as the «Desert », a metaphor Hillel Schwartz explains " at once for the spiritual desolation of Huguenots in Southeastern France and for the geography of their assemblies " ${ }^{2}$. In this atmosphere of religious tension, charged with apocalyptic fears and hopes, the emergence of prophets appeared to the resister to be a convincing and powerful affirmation of the position he had chosen. The prophets brought to their movement a new spiritual source of divine approbation that carried a promise of victory. The undaunted Huguenots felt that Peter's address on the day of Pentecost applied to them and legitimized their words and actions :

" And it shall come to pass in the last days, says the Lord, that I will pour forth of my Spirit upon all flesh; and your sons and your daughters shall prophesy... And moreover upon my servants and upon my handmaids in those days will I pour forth of my Spirit, and they shall prophesy " (Acts 2, $17 / 18)$.

The question of discernment of true from false inspiration was raised from the moment on the night of February $3^{\text {rd }}, 1688$, when the unlearned shepherdess Isabeau Vincent uttered her prophetic message; it persisted as military leaders in the Camisard War claimed they were proceeding under inspiration by the Holy Spirit, and as prophesying continued twenty years later in exile in England and on the Continent. The Royal authorities and the Catholic clergy proceeded without mercy to denounce and persecute the prophets as charlatans and imposters who were justifying their outrageous and criminal behavior ${ }^{3}$.

The impact of the resurgence of prophetic utterrances among French Protestants in the period shortly before and during the Camisard War and later in exile is a subject that attracts increasing scholarly attention.

The sermon Le Moyen de discerner les esprits ou sermon sur la première Épitre de saint Jean, ch. 4, vers. 1 (February 1689) by the Huguenot pastor Elie Merlat (1634-1705) at Lausanne, is one of the earliest, if not the first, strong and carefully argued refutation of the claims of the new prophets by a leading pastor of the French Reformed Church and author of widely renown works on theology and political theory.

The Huguenot ministers who were forced into exile faced the alternative of defending the authenticity of the miraculous phenomenon of prophecy or joining the Catholic enemy in declaring it a fraud. The news of

2. Hillel Schwartz, The French Prophets, Berkeley, University of California Press, 1980, p. 14.

3. Cf. David Augustin DE BrueYs, Histoire du fanatisme de notre temps, Paris, F. Muguet, 1692. 
the emergence of new prophets was received by their cor-religionists in exile as enthusiastically as it was in the homes of the Dauphiné. Pierre Jurieu (1637-1713) in his widely circulated Lettres pastorales lent his voice in support of the genuineness of the « Ecstasis of Isabel Vincent [...] who has sung Psalms, Prayed, Preached and Prophesied about the Present Times in her Trances $"{ }^{4}$. This opinion by a leading theologian of the Refuge was highly welcomed and shared among others by one of the major activists of the Refuge, Claude Brousson (1647-1698), a Toulouse lawyer ordained in exile in Lausanne in 1694, who not only joined in celebrating the Prophets as witnesses to the truth of the Protestant church under fire but challenged fellow pastors to return from exile to their abandoned flock. Such was the course he chose; inevitably it led to martyrdom and death. Brousson was executed at Montpellier in November 1698.

The French pastor Elie Merlat, in exile in Lausanne, could not fail to question the testimonies of the new prophets if he was to deal honestly with a challenge to his theological understanding. The teachings of the Reformed Church denied the veracity of all miracles and claims of direct inspiration by the Holy Spirit after the Apostolic Age. In making his views known at this historical moment and in light of fervent popular and learned approval of the prophets, it must be recognized that he demonstrated either courage or folly and disloyalty.

Elie Merlat (1634-1705) was born to a family at Saintes on the Charente River; a lawyer's son, he pursued his studies for the ministry at the Academies of Saumur and Geneva. Among his teachers at Saumur was Moïse Amyraut (1596-1664) whose political theories on sovereignty continued to influence Merlat through later years. He apparently was not swayed by Amyraut's interpretation of Calvin's teachings on predestination, which orthodox Calvinists labeled «Universalismus hypotheticus ${ }^{5}$. Merlat's adherence to a rigid exegesis is evident from a letter to François Turrettini of October 13, 1675, the same year in which the latter prepared his orthodox Formula Consensus Ecclesiarium Helveticarum Reformatorum, which is highly critical of Saumur theology. Merlat wrote :

"Votre église vous fournit de si grands exemples et les Calvins [...] ont eu tant de peine avant vous à réduire les rebelles à l'ordre d'une sainte discipline, que le succès que Dieu donna à leur fermeté doit vous rendre inébranlable $"{ }^{6}$.

4. Pierre Jurieu, Lettres pastorales. Seconde année. III. Lettre, Rotterdam, A. Acher, 1688.

5. Rudolf PfISTER, Kirchengeschichte der Schweiz, Zürich, Theologischer Verlag, 1974, vol. II, p. 422.

6. Eugène DE BUDÉ, Vie de François Turrettini, théologien genevois, 1623-1687, Lausanne, G. Bridel, 1871, p. 217. 
Returning from the customary tour for a young Protestant theologian to Switzerland, Germany, Holland, and England, he settled as pastor in his home town, Saintes, in 1658.

In 1676 at the end of twenty years of exemplary pastoral service in the face of civil and clerical harrassment, Merlat enraged the authorities with a defense of the morality of Calvin's doctrine of justification against the attack Le Renversement de la morale de Jésus-Christ (1674) by the Jansenist theologian Antoine Arnauld ${ }^{7}$. A year earlier incidentally, Pierre Jurieu had also replied to Arnauld's criticism of the Reformed teachings on justification ${ }^{8}$. The final blow came in 1679. Trumped-up charges by the Bishop of Saintes that Merlat had spoken irreverently of the King in his sermons, subjected him to cruel investigation, followed by one year of imprisonment and banishment from France 9 . The absurdity of such accusations is most evident, not without a sadly ironic twist, in the Traité du pouvoir absolu des souverains, a defense of Royal Absolutism by Merlat, himself the very victim of such powers, published only a few weeks before the Edict of Revocation in October 1685. Not differing from Jurieu, who remained a firm Royalist till 1688, Merlat understood Calvin's teachings on obedience of subjects to their rulers as excluding any active resistance ${ }^{10}$. The only form of disobedience, in case the Princes' actions offend the moral conscience of the believer, is of a purely " passive or silent nature ${ }^{11}$.

Upon release from severe imprisonment, Merlat sought refuge in Switzerland. He was welcomed at Lausanne and appointed to positions as first pastor and as teacher at the "venerable " Academy. In the year of the Revocation of the Edict of Nantes, Merlat filled the post of Rector and he continued to teach till 1687 , after which he devoted himself exclusively to the ministry until his death in $1705^{12}$. In the years of his rectorate he set an example to fellow pastors of the Refuge by signing the Helvetian Formula Consensus of 1675, a strictly orthodox Reformed

7. Élie MerLat, Le Renversement de la morale de Jésus-Christ par les Calvinistes, Saumur, chez René Pean, 1676.

8. Orentin Douen, Les Premiers pasteurs du Désert 1685-1700, Paris, Grassart, 1879, vol. II, p. 237.

9. Nathanaël WEISS, «Quelques épisodes de la Réforme à Saintes et en Saitagone », Bulletin de la Société de l'histoire du protestantisme français, vol. 42, 1893, p. 386-387.

10. Cf. Jean Calvin, Institutes of the Christian Religion, Bk. IV, chap. 20, 23 ("Obedience "), Philadelphia, Westminster Press, 1960, vol. II, p. 1510-1511.

11. Wladyslaw Jozef Stankiewicz, Politics and Religion in Seventeenth-Century France, Berkeley, University of California Press, 1960, p. 170. Cf. also A. GaLland, " Les pasteurs français Amyraut, Bochart, etc. (Dubosc, Claude, Jurieu, Merlat) et la royauté de droit divin ", Bulletin de la Société de l'histoire du protestantisme français, vol. 77, 1928, p. 418-421.

12. R. Pfister, op. cit. supra n. 5, p. 545-546. 
Confession. As preacher at Lausanne for twenty years, a time-span equal to his service to his home church, he delivered sermons which went straight to the heart of the matter and captivated the audience. From this brief account it seems evident that Elie Merlat was deeply rooted in orthodox Reformed theology, able to defend his faith, for which he was ready to suffer, with theological and juridical arguments. This characterization remains incomplete without reference to his compassion for his fellow refugees and for less advantaged parishioners ${ }^{13}$.

Henry Vuilleumier, in his comprehensive history of the Reformed Church of the Vaud, credits Merlat with having spearheaded a sober reappraisal of the prophetic epidemic. He did not hesitate to confront prejudicial opinion and try to change public sentiments ${ }^{14}$. With that aim in mind he spoke from the pulpit on January $11^{\text {th }} 1689$ and subsequently published his sermon Le Moyen de discerner les esprits (February 1689) ${ }^{15}$. The quotation following the title from the first verse of the fourth chapter of the First Letter of John, "Beloved, do not believe every spirit, but test the spirits to see if they are of God ", becomes the leitmotiv of the sermon. Merlat is well aware of the singular position he is taking and of the fact that he is laying himself open to an accusation of unbearable conceit (self-glorification). « Gens de bien, lors qu'ils sont forcés à prendre parti, contre la plus-part des autres hommes » (p. 2) and Merlat does not hesitate to recall the greatest examples from Biblical times, Micah and David, Jesus-Christ abandoned by his disciples and from history, Wycliffe, Hus and Luther. "L'explication du texte " that he will offer, braving an impetuous torrent, justifies these references (p. 3).

The situation which impells Merlat to speak out is the reception the new prophets in the Dauphiné, claimants of divine inspiration, received among his fellow Protestants. The reaction cannot be understood nor dealt with before the events precipitating it are discussed. Merlat sets out to unmake the "prétendus Inspirés ", using the common derogatory adjective attached to Protestants in official documents, and embarks on a devastating analysis of their reception. This enables him to bring in proper focus the leitmotiv, the quotation from the First Letter of John, as the lesson on which the sermon is preached. The advice the message carries is twofold : First not to trust all sorts of spirits, which prevents us from coming hastily to false conclusions. The second demand is to test the spirits if they are of God, which suggests the necessity for finding correct means to determine the truth. Satan, in his desire to undermine the

13. C. Bost, op. cit. supra n. 1, vol. I, p. 283.

14. Henri VullLeumier, Histoire de l'Eglise réformée du Pays de Vaud, Lausanne, Ed. La Concorde, 1930, vol. III, p. 205.

15. All page references in the text are to this edition. 
power of Jesus to bring salvation to humans, from the very beginning sent out emissaries who convinced certain persons in their vainglory to believe that they received divine inspiration. Thus they were turned into counterfeiters of the inspiration by the Holy Ghost, and possessed by demons "qu'ils ne discernoient, peut-être pas eux-mêmes" (p. 7). To them applies the Apostle John's designation of «false prophets " that concludes the verse of the leitmotiv.

The warning of the Apostle implies the actual danger of the doings of false spirits, in other words of the Devil (p. 9-10). Merlat evokes the powers of the Devil who by his magic tricks enchants man's senses, alters the condition of body and mind, and bends the will of his subject (p. 32). A vivid description was to be provided by Mephisto's Witch's kitchen in Goethe's Faust. Yet, the Devil can play his role only with the permission of God, who also sets the limits.

The text of the letter of John calls for seeking discernment. Merlat supplements the quotation with further references to passages in the Old and New Testaments in which similar demands are expressed. These compel him to "réduire icy cette matière en méthode, et en faire un Système " that will enable one to identify « des marques certaines de la perfection divine ".

The short definition : «L'Inspiration divine est une action immédiate de l'Esprit de Dieu », provides the starting point (p. 22-23). Merlat differentiates two types of Inspiration. The one is positive, characterized by divine perfection and its divinity is assured. The other is of a negative character, with imperfection proving that it has been mistaken for divine Inspiration. The human creature becomes the ground on which these forces, the positive and the negative, encounter each other. In order to discern the true act of God from its counterfeit in each case those sure marks of divine action that exclude deceit have to be identified. Of universal validity above all is the maxim that " nous n'admettions jamais pour Divin, ce qui est, ou contre la Parole de Dieu " (p. 24). This maxim Merlat incorporates and he lists, as in good Ciceronian rhetoric, the seven commonplaces from which arguments to discern true inspiration can be drawn. Among these is the assertion that nothing that is repugnant to the order of divine wisdom or to perfect saintliness can be of divine Inspiration. By the same token that which shows vanity, superfluousness, malice, or moral turpitude, cannot derive from divine Inspiration. Prophecy « or to predict matters of the future " belongs to God. As God allows the Devil to imitate prophesying, the greatest caution must be taken to escape his deception. God's knowledge is infinite and in testing his creatures he reaches in the depth of the human heart.

With these general principles in mind, Merlat addresses the prophecies of the «prétendus Inspirés » of the Dauphiné. He advises his audience 
that he will first render an account of what he has learned concerning the prophets, secondly examine the reasoning of those who are convinced that their inspiration is genuine and divine, thirdly prove their notions false, and finally try to draw some lessons from those extraordinary events that will inform and console the truly faithful (p. 33). Merlat chooses as a representative example the story of the shepherdess Isabeau Vincent of Crest on the Drôme River, the first to prophesy under the spell of inspiration.

The girl of thirteen or fourteen, poorly educated, raised at first in the Protestant faith by her father, who later converted to Catholicism under the pressure of the Dragonnades, had left the paternal home to live with an uncle. In the night of February 2, 1688, she came for the first time under a seizure, her body began to tremble « approchant des symptomes de l'Epilepsie " (p. 34), upon which she fell in a deep sleep from which she could not be awakened. In that state she started to recite psalms, that she had not previously been taught, and began to preach repentance, to condemn Mass, and to exhort those who had converted to return to the Protestant church. She added some predictions, the promise of deliverance from persecution due to a fundamental change in the kingdom by the time of vintage. Such, in substance, was the gist of her message, delivered in profound sleep again and again over several months. Merlat's summary is based on the accounts of Pierre Jurieu, supporting the belief that Isabeau had been under divine inspiration, and of Esprit Flechier, Bishop of Nìmes, denouncing her as a fraud. Merlat adds to this report an incident alleged by Fléchier ${ }^{16}:$ "Après une sérieuse et forte exhortation à la repentance, elle retira ses mains, qui paroissoient sur le lit, et couvrit aussi son visage de la couverture, et se mit à rire avec éclat " (p. 34). Merlat begins by posing nine arguments in support of the prophets, which he parries with corresponding counterarguments, and he can rightly boast that he has recorded those arguments that were considered most convincing for the claims of the prophets (p. 41). Starting with the assertion of God's omnipotence, from which the logical conclusion is drawn that he is not restrained from doing now what he has done in the past, the door is opened to admit a continuing revelation and divine inspiration. The events on the day of Pentecost and the words that Peter spoke according to the Book of Acts become the paradigm for those claiming to receive inspiration by the Holy Spirit. The excruciating situation in which the Huguenots find themselves, their Church abolished, their ministers banned, forced to attend Catholic services - is it not to be compared with the times of the Apostles?

16. Esprit FléCHER, Lettres choisies, Paris, 1715, vol. I, p. 399-414. 
To find children prophesying, singing psalms and speaking out as they did on the arrival of Jesus at Jerusalem could only be taken as an affirmation of the righteousness of their cause. There could be no better description of such happenings in the desert than the words of the Psalmist : "You have exalted your majesty above the heavens. Out of the mouths of babes and sucklings you have fashioned praise... " (Ps. 8, 2-3).

Prophecies concerning impending events, though not entirely accurate, presaged a change of historic magnitude, England's turning from adversary to ally of the Huguenot cause.

The strongest evidence of the power and veracity of the messages is their content. Mass is condemned, the Apostate reprimanded, repentance preached, the true Confession taught, and God is invoked with ardent prayer (p. 44). Merlat presented an imposing array of arguments in defense of the Inspirés. The major thrust of his refutation follows the counterarguments, from which he moves quickly to evoke the consequences to which false inspiration may lead. The sermon reaches a crescendo in its final part, with a powerful condemnation of the Dauphiné prophets and of their supporters, both deceived and deceivers.

Nobody denies that it is possible for God to create prophets but it does not follow that this potentiality will be realized. With that Aristotelian comment Merlat dismisses the first argument. The idea that children are chosen to become preachers is plainly ludicrous. Children calling hosanna cannot be supposed to exercise the function of ministers. In answer to the remaining arguments that emphasize the conformity of the messages to the teaching of the Reformed Religion, Merlat declares it is in the Devil's interest and power, clothed in virtue, to delude even the sage (p. 46-49). The claim to prophesy historical events is the most arrogant and the least convincing of all. A promise that deliverance from persecution will come by the time of vintage, with no specification of month or year, is so vague that it is to be discounted as prophecy. In regard to the developments in England and the role of William of Orange, Merlat rejects any prophesies affecting the present calamities of the Dauphiné (p. 49-50).

At this turn of the sermon Merlat is set to launch his strongest attack, directed towards the ministers among his audience. He raises the specter of the Anabaptist revolt at Münster, which never ceased to haunt Protestant churches. John of Leiden proclaimed in the name of the Holy Spirit, the same that had descended upon the Apostles, that the town of Münster would become the New Jerusalem. With a few other leaders, he established a reign of terror, declaring all goods to be communal property and sanctioning polygamy. Merlat asks : 
«Cependant ce miserable Antechrist moderne, ne parvint à ce haut degré de forcénerie, que par des voyes aussi bonnes, dans leur première apparence, que celles des Inspirés dont nous parlons. La liberté chrétienne, la tyrannie du Pape, l'iniquité du Siècle [...] la communauté apostolique des biens [...] donnèrent du crédit à cet imposteur " (p. 54).

Yet we know what really happened in Münster « et que Satan ne se découvre, qu'après une infinité des gens se sont perdus " (p. 54). If such was the consequence of Anabaptist teaching it is important to point to its source, the revolutionary theologian Thomas Müntzer. When he first started to preach, he was capable of deceiving « Luther même, ce grand Luther, instrument de Dieu pour la Réformation " (p. 55), until, under divine inspiration, he unleashed violent attacks against all authorities and excited the minds of the German peasants to revolt ${ }^{17}$. These were the fearful examples of the dangers to which claims of divine inspiration may lead. Merlat admits that the Inspirés of the Dauphine «sont de povres innocens, des enfans, des filles, pour la plus-part " (p. 60) compared to the followers of Müntzer and John of Leiden, their arms in hand. Though one cannot compare the German peasants with those of the Dauphine who are still in the stage of mystic passivity, the story of Münster is a warning to be heeded. Merlat did not prophesy but warn. Yet events, starting with the expedition under divine inspiration to free the prisoners at Pontde-Montvert and the ensuing murder of the superintendent l'abbé du Chailard on July 24,1702 , generally considered the immediate cause of the outbreak of the Camisard War, proved that Merlat's fears of a turn to violence were justified ${ }^{18}$. Merlat followed the passage on Müntzer with a passionate statement, deviating from its otherwise sober tone :

« Je dis donc que loin de pouvoir souffrir que l'on admette cette inspiration, je la soûtiens manifestement fausse, et diabolique [...] Et j'oze dire que l'opinion commune, est une marque déplorable de l'abandon où nous sommes " (p. 61).

Merlat does not shrink from making his fellow Protestant ministers responsible for allowing public opinion to form in support of the fantasies of the Inspirés. These ministers of the Refuge cry miracles to extoll the Ins-

17. E. Merlat quotes extensively from an address by Thomas Müntzer to the peasants at Frankenhausen before the battle. This talk is printed in Historien von Thomas Müntzer (Hanau, 1525), believed to have originated in the circle around Müntzer. Cf. Walter ElLIGER, Thomas Müntzer, Göttingen, Vandenhoeck und Ruprecht, 1975, p. 77.

18. Abraham Mazel, Elie Marion, Jacques Bonbonnoux, Mémoires sur la guerre des Camisards, Montpellier, Presses du Languedoc, 1983, chap. I, p. 4-9. 
pirés, contrary to all Reformed principles and to their own canon. In order to find an explanation for their deception, Merlat turns to a psychological interpretation. Deep feelings of guilt must hound the ministers in exile who were forced to abandon their flock in disregard of the command given by Jesus to Simon Peter, « Feed my lambs » (John 21, 16) and of the example of the good shepherd who "lays down his life for his sheep " (John 10,11). The eagerness of the ministers to grant veracity and even to glorify the Inspirés, Merlat suggests, may be caused by their own bad conscience and awareness that they had not fulfilled God's command. If the self-appointed Prédicants and the Inspires can carry on pastoral services and functions in their absence, the ministers can feel that their flock is not abandoned. Merlat, himself in exile, might have experienced inner turmoil of this kifid to prepare him for his profound understanding of the ministers' dilemma. In fact Claude Brousson, who later returned to the Dauphine to be martyred, engaged in a controversy over the issue with Merlat ${ }^{19}$.

The final task Merlat set for his sermon was to examine the consequences of what he unmasked and condemned as false inspiration. The Reformed Church always insisted that only those texts recorded in the Bible constituted Holy Scriptures. For this very reason the Reformers, who never boasted of performing miracles or being the recipients of divine inspiration, separated from the Roman Church (p. 62). Merlat raises the rhetorical question : what purpose would be served by a continuing inspiration, bestowed on persons of both sexes and all ages? Prophecies and miracles recorded in the Old and New Testament never originated with the many but with the very few, Moses and Aron, Elijah, Micah and Jesus. "Le party du mensonge et de l'Erreur ", as Merlat characterizes the Roman Church, is recognized by its infinite claim of inspiration (p. 67).

The miserable people who today believe or pretend to believe they are inspired are receiving the punishment that is due to them. They who possessed the true Reformed faith have become apostates. "Ils sont dignes de périr par le motif du zèle, comme les juifs; et d'être livrés entre les mains des Romains, pour avoir crucifié derechef le Segneur de gloire " (p. 70). The fervor of the following concluding injunction might be best explained by Merlat's wish to reach all those who, under the impact of recent radical Pietist agitation in the Vaud country, became more susceptible to enthusiastic and millenarian religious expressions.

19. O. DUUf, op. cit. supra n. 8, p. $241,425$. 
«Quand à vous Fidèles, qui jouissés agréablement du doux fruit de votre Exil volontaire, par la liberté présente de vos consciences [...] au nom du Père des Esprits [...] je vous prie [...] Tenez-vous fermès à la vérité connue ; n'y ajoutez rien ; n'en diminuez rien. Regardez, du port, avec étonnement, \& avec pitie, ces povres malheureux, qui sont dans le naufrage, qui luttent contre les flots, \& qui se noyent. Tirez-les à bord, autant que vous pourrez; recueillez ceux qui y viennent; envoyez mêmes vos batteaux pour les sauver : Mais ne périssez pas misérablement, avec ceux d'entr'eux qui s'enfoncent dans les ondes, ou qui s'exercent volontairement à y pager, au lieu d'en sortir. Laissez-là ces vaines, fantasques, \& ridicules opinions, de l'Inspiration de ces povres mal-heureux. Au lieu d'applaudir à leurs prétendus avantages, ayez horreur de leur extréme aveuglement, \& joignez-vous à nous pour les en tirer " (p. 87-88).

Rather incredulous when learning of Merlat's sermon, Pierre Bayle wrote to his friend David Costant: «Mais, au reste, et-il vrai que Mr. Merlat ait prêché de toute la force, que c'était un pur Quvrage du Démon. Cela est capable de la rendre plus odieux que son Traité du Pouvoir absolu des Souverains " 20 . Elie Merlat's idea, if not of his self-image, of the exegete of Scripture, was " un Pasteur eclaịré, et propre à ensegner » (p. 15). A reading of the text of his sermon gives convincing proof that he fulfilled such sober aspirations. He was ready to stand and speak up for his convictions, however unpopular they were.

\section{Walter Grossmann "', University of Massachusetts.}

20. Pierre Bayle, Lettres choisies, Rotterdam, 1714, vol. I, p. 259.

21. I am grateful to Fondation de la Maison des sciences de l'homme for its support. I would also like to thank the Bibliotheque de la Societe de l'histoire du protestantisme francais. This study was first given as a paper at the Herzog August Bibliothek Wolfenbuttel in October 1988. 